\title{
Effects of Suillus collinitus (Fr.) Kuntze extracts on genotoxicity and proliferation of human lymphocytes
}

\author{
Bugrahan EMSEN*๑, Asuman TÜREL@, Yasin UZUN॰ \\ Department of Biology, Kamil Özdă̆ Faculty of Science, Karamanoğlu Mehmetbey University, Karaman, Turkey \\ *bugrahanemsen@gmail.com
}

Received : 15.08 .2109

Accepted : 09.09.2109

Online : : 13.09.2109

Suillus collinitus (Fr.) Kuntze ekstraktlarının insan lenfositlerinin
genotoksisitesi ve proliferasyonu üzerindeki etkileri

Abstract: Cultivated or wild edible mushroom species have traditionally been used by humans for medical purposes for many years. Edible mushrooms have the potential to show different activities due to the numerous bioactive components they contain. In particular, some mushroom species whose regulatory properties have been identified on human immunity are of interest in the scientific world. Considering these characteristics of edible mushroom species, in the present study, it was examined the effects of Suillus collinitus (Fr.) Kuntze, an important edible mushroom species, on human peripheral lymphocytes. For this purpose, acetone and water extracts were obtained from S. collinitus and the effects of these extracts on genotoxicity and proliferation of human lymphocytes were tested by chromosome aberration (CA), micronucleus (MN), nuclear division index (NBI) and mitotic index (MI) analyses. When genotoxicity analyses were examined, it was found that none of the tested extract applications (1$100 \mathrm{mg} / \mathrm{L}$ ) did not change the CA and $\mathrm{MN}$ frequencies statistically $(p>0.05)$ compared to the negative control group. Proliferation analyses showed that only the maximum concentration $(100 \mathrm{mg} / \mathrm{L})$ application of acetone extract of $S$. collinitus decreased the NBI and MI ratio of the cells at a level of $p<0.05$ compared to the negative control group. The obtained results revealed that the acetone and water extracts of $S$. collinitus, especially the applications at concentrations of 1-50 $\mathrm{mg} / \mathrm{L}$, did not show any genotoxic or cytotoxic activity on lymphocytes involved in the human immune system.

Key words: Cytotoxicity, Genotoxicity, Lymphocyte, Suillus collinitus

Özet: Kültüre edilmiş veya yabani yenilebilir mantar türleri yıllardır insanlar tarafından geleneksel olarak tıbbi amaçlı kullanılmaktadır. Yenilebilir mantarlar içerdikleri kendilerine özgü çok sayıda biyoaktif bileşen sayesinde farklı aktiviteler gösterme potansiyeline sahiptir. Özellikle insan bağışıklığı üzerinde düzenleyici özellikleri tespit edilen bazı mantar türleri bilim dünyasında dikkat çekmektedir. Yenilebilir mantar türlerinin bu özellikleri göz önünde bulundurularak, mevcut çalışmada önemli yenilebilir bir mantar türü olan Suillus collinitus ( $\mathrm{Fr}$.) Kuntze'un insan periferal lenfositleri üzerindeki etkileri incelenmiștir. Bu amaçla, S. collinitus'tan aseton ve su ekstraktları elde edilmiş ve bu ekstraktların insan lenfositlerinin genotoksisitesi ve proliferasyonu üzerindeki etkileri, kromozom aberasyonu (KA), mikronükleus $(\mathrm{MN})$, nükleer bölünme indeksi (NBI) ve mitotik indeks (MI) analizleri ile test edilmiștir. Genotoksisite analizleri incelendiğinde, test edilen ekstrakt uygulamalarını (1-100 mg/L) hiçbirinin negatif kontrol grubuna kıyasla KA ve MN frekanslarını istatistiksel $(p>0.05)$ olarak değiştirmediği tespit edilmiştir. Proliferasyon analizleri ise yalnızca $S$. collinitus'un aseton ekstraktının maksimum konsantrasyonlu $(100 \mathrm{mg} / \mathrm{L})$ uygulamasının, hücrelerin NBİ ve Mİ oranını negatif kontrol grubuna kıyasla $p<0.05$ düzeyinde düşürdüğünü göstermiştir. Elde edilen sonuçlar, S. collinitus'un aseton ve su ekstraktlarının özellikle 1-50 mg/L konsantrasyonlu uygulamalarının, insan bağışıklık sisteminde görevli lenfositler üzerinde herhangi bir genotoksik veya sitotoksik aktivite göstermediğini ortaya çıkarmıştır.

Anahtar Kelimeler: Sitotoksisite, Genotoksisite, Lenfosit, Suillus collinitus

\section{Introduction}

Mushrooms serving as a good food source for many years are valuable nutrients due to their high protein and vitamins, low fat content, fiber, carbohydrates and minerals (Kalač, 2013; Valverde et al., 2015). While some of the edible mushrooms are produced in culture, most of them are wild edible. Wild edible species are used in traditional medicine, especially in Asian countries (Pala et al., 2013). The important biologically active components of these mushrooms increase their pharmacological importance (De Silva et al., 2013; Khatua et al., 2017; Benítez et al., 2017).

The mushrooms are used effectively in the treatment or prevention of many diseases by extracting the active substances in their compositions because of their nutritional and medicinal properties. There are many species of edible mushrooms that have been found to have antitumor, cardiovascular, antimicrobial and immunoregulatory properties (Randhawa and Shri, 2018; Su et al., 2019). The effects of the mushrooms, especially on the immune system, have increased their importance in recent years. The reason for this is the weakening of the immune system, which is the leading cause of many different diseases (Zhao et al., 2018; Nguyet et al., 2018). Certain phenolic compounds, purines, quinones, terpenoids and phenyl propanoid-derived antogonistic agents, which are generally fungal-specific, are among the important components that regulate the immune system (Hsieh and Wu, 2011; Gill et al., 2018; Chirapongsatonkul et al., 2019). In this context, it is important to maintain the number of lymphocytes in the immune system and not to cause any cytotoxic or genotoxic damage. Because many therapeutic agents have positive effects on the other hand, they can weaken the immune system and cause different diseases (Emsen et al., 2019). Genetic damage to the cells can cause many permanent diseases. Subsequent genetic defects such as structural changes on chromosomes can be transmitted for generations (Gabory et al., 2009; Algar et al., 2011). For all these reasons, it is necessary to pay attention to the supplementary nutritional products taken into the body. Numerous scientific studies have shown 
that the use of edible mushroom species as supplementary food does not cause any genetic damage or even strengthens the immune system (Emsen and Guven, 2019; Wang et al., 2019).

Considering the aforementioned characteristics of edible mushrooms, studies on the different biological activities of Suillus collinitus (Fr.) Kuntze a have been found to be limited. Moreover, to our best knowledge, it was found that their effects on lymphocytes, the most important element of the immune system, were not detected. Therefore, in this investigation, it was aimed to explore the role of $S$. collinitus acetone and water extracts in human lymphocytes by using chromosome aberration (CA) and micronucleus (MN) tests.

\section{Materials and Method}

\subsection{Collection and Identification of the Mushroom Samples}

S. collinitus samples were collected from Islahiye district of Gaziantep province $\left(36^{\circ} 56^{\prime} \mathrm{N}-36^{\circ} 31^{\prime} \mathrm{E}, 520 \mathrm{~m}\right)$ of Turkey. Samples photographed in their natural environment were brought to fungary. The samples were dried and identified via literature. (Breitenbach and Kränzlin, 1995; Jordan, 1995; Desjardin et al., 2014).

\subsection{Preparation of the Extracts}

$15 \mathrm{~g}$ of the mushroom specimens were dried under room conditions and powdered with liquid nitrogen. Then acetone (SCAE) and water (SCWE) extracts of $S$. collinitus were obtained by $250 \mathrm{~mL}$ solvent systems. Soxhlet extraction apparatus was used for the extraction process. The crude extracts obtained by rotary evaporator were dissolved with distilled water and made ready for testing.

\subsection{CA Assay}

The heparinized blood was mixed with chromosome medium (Chromosome Medium B, Merck, Berlin). Blood cultures were incubated for $24 \mathrm{~h}$ and then different concentrations $(1,5,10,25,50$ and $100 \mathrm{mg} / \mathrm{L})$ of the studied mushroom extracts were added to the cultures. In addition, a positive control (PC) (Mitomycin-C $\left(\mathrm{C}_{15} \mathrm{H}_{18} \mathrm{~N}_{4} \mathrm{O}_{5}\right.$, Sigma, St, Louis/MO, USA, at $\left.\left.10^{-7} \mathrm{M}\right)\right)$ and negative control (NC) group with no extract were included to the treatments. The culture was continued for a total of $72 \mathrm{~h}$ at $37^{\circ} \mathrm{C}$. After colchicine (Sigma, St, Louis/MO, USA) application, the culture tubes were centrifuged for 10 minutes at $900 \mathrm{rpm}$ and the cells were were resuspended with $\mathrm{KCl}$. Then, the cells were exposed to freshly made fixative consisting of methanol; glacial acetic acid 3:1. Fixed cells then were dropped onto clean, wet slides, dried and stained with 3\% Giemsa solution in phosphate buffer ( $\mathrm{pH}$ 6.8) for $15 \mathrm{~min}$. Furthermore, mitotic index (MI) analysis was calculated based on formula: $\mathrm{MI}=$ (number of cells in mitosis / total number of cells) $\times 100$.

\subsection{MN Assay}

In this experiment, similar applications to chromosome protocol were performed. Briefly, the heparinized blood was mixed with chromosome medium (Chromosome Medium B, Merck, Berlin). Five samples of the extracts at different concentrations $(1,5,10,25,50$ and $100 \mathrm{mg} / \mathrm{L})$ were added to cultures $24 \mathrm{~h}$ after the beginning of incubation. In addition, PC (Mitomycin-C, $10^{-7} \mathrm{M}$ ) and negative $\mathrm{NC}$ group with no extract were included to the treatments. $44 \mathrm{~h}$ after the beginning of incubation cytochalasin B (Sigma, St, Louis/MO, USA) was added to the culture tubes. After fixation process, the cell suspensions were dropped onto clean slides, air-dried and stained with $3 \%$ Giemsa solution. 1000 binuclear cells per concentration were examined for $\mathrm{MN}$ scoring and to determine the number of cells with $1,2,3$ and 4 nuclei. Nuclear division index (NDI) was calculated using the formula NDI $=[(1 \times \mathrm{N} 1)+(2 \times \mathrm{N} 2)+(3 \times \mathrm{N} 3)+(4 \times \mathrm{N} 4)] / \mathrm{n}$ (total cell count). In this formula, N1-N4 represents the number of cells with 1 to 4 nuclei.

\subsection{Statistical Analyses}

Genotoxicity and proliferation activities of the extracts were analysed one-way ANOVA followed by Duncan test. All analyses were done using SPSS (version 21.0, IBM Corporation, Armonk, NY, USA).

\section{Results}

\subsection{Genotoxic/CA and MN Activities}

Based on CA test, only PC $(0.88 \mathrm{CA} /$ cell $)$ caused significant $(p<0.05)$ increases in $\mathrm{CA}$ frequencies on lymphocytes compared with the $\mathrm{NC}(0.20 \mathrm{CA} /$ cell $)$. However, the mushroom extracts at all applied concentrations did not indicate significant differences $(p>$ 0.05 ) in CA analyses (Figure 1).

The genotoxic effects of SCAE and SCWE on lymphocytes were analysed by MN test. As in the CA test, none of the mushroom extracts statistically $(p>0.05)$ produced a different result than the NC experiment. The $\mathrm{MN}$ frequency revealed by PC application was very high (5.92 MN/1000 cells) compared to the other applications (Figure 2).

\subsection{Proliferative/MI and NDI Activities}

MI, which refers to the ratio of mitotic division cells to all cells in the lymphocyte population, plays an important role in proliferation studies. MI gave an idea about the cytotoxic effects of the extracts on the human peripheral lymphocytes. Based on MI analyses, PC application had the lowest percentage $(2.07 \%)$ and this value was statistically $(p<0.05)$ different from other MI data. MI percentage was 5.39 for $\mathrm{NC}$ treatment. As for the extract experiments, MI values caused by SCWE were statistically $(p>0.05)$ indifferent from NC. The maximum

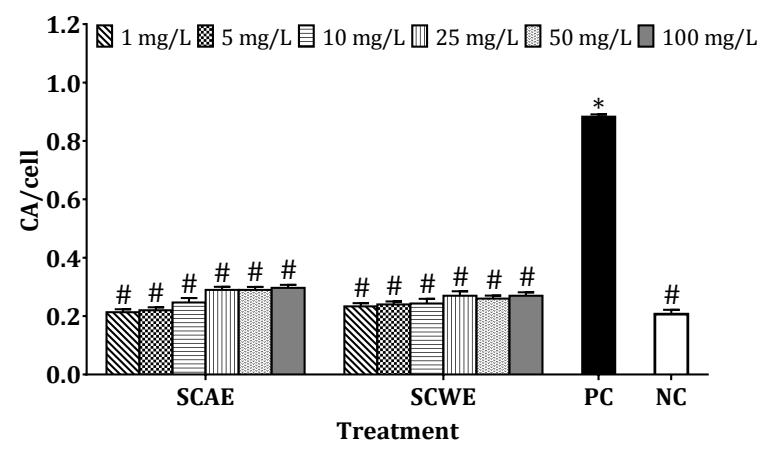

Figure 1. Frequencies of CA in the lymphocytes exposed to $S$. collinitus extracts. Each value is expressed as mean \pm standard deviation $(n=3)$. * and \# symbols indicate statistical difference $(p<0.05)$ from NC and PC, respectively. 


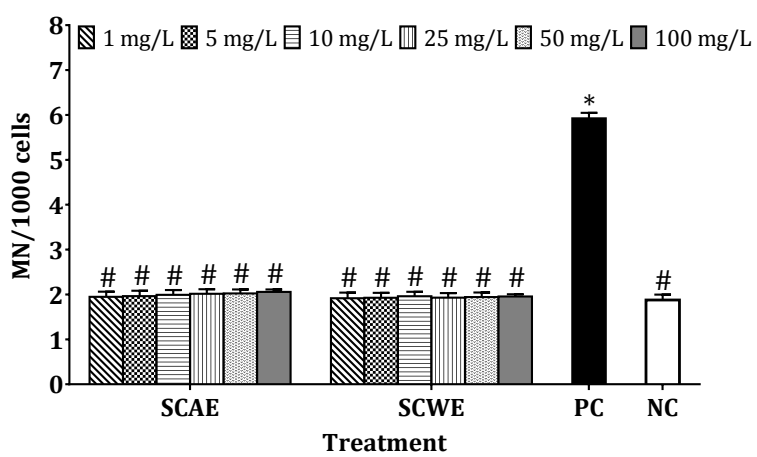

Figure 2. Frequencies of $\mathrm{MN}$ in the lymphocytes exposed to $S$. collinitus extracts. Each value is expressed as mean \pm standard deviation $(n=3)$. * and \# symbols indicate statistical difference $(p<0.05)$ from $\mathrm{NC}$ and $\mathrm{PC}$, respectively.

concentration $(100 \mathrm{mg} / \mathrm{L})$ application of SCAE decreased the MI ratio $(5.09 \%)$ of the cells at a level of $p<0.05$ compared to NC (Figure 3).

Similar results to CA were obtained in NDI analysis. PC had the lowest NDI rate (1.19) among the trials. NC with the highest NDI ratio of 1.64 led to a comparison. While any treatments of SCWE did not cause a significant $(p>$ 0.05 ) change on the cells compared to $\mathrm{NC}$, the maximum concentration $(100 \mathrm{mg} / \mathrm{L})$ application of SCAE decreased the NDI (1.39) of the cells at a level of $p<0.05$ compared to NC (Figure 4).

\section{Discussion}

It is known that any medication taken into the body has side effects. In this case, it is important to improve the target disease and keep the side effect as low as possible (Kumar et al., 2012). The side effects of many herbal products used under the heading of alternative treatment are negligible by using certain doses. In this context, edible mushrooms are important organisms. The fact that these mushrooms can be easily grown organically increases the importance of the mushrooms. In terms of nutrition, it contains low calories and a rich content of essential amino acids, carbohydrates, fibers, important vitamins and minerals (Wang et al., 2014; Sangeetha et al., 2019). Mushrooms have also been used as medicines in eastern countries for centuries. Many edible mushroom species analysed for their medicinal properties have been found to contain many active ingredients. These compounds have been shown to strengthen the immune system, have anti-carcinogenic and cholesterol-lowering properties and act as protective agents against hepatitis (De Silva et al., 2012; Rahman et al., 2018).

S. collinitus mushroom used in the present study is one of the important edible species on which different investigations have been carried out. It has been found that mushrooms are a source of essential fatty acids in a diet rich for human nutrition (Ergönül et al., 2012; Zengin et al., 2015). Some biological activities of extracts containing different bioactive components of $S$. collinitus are available in the literature. It was reported that methanolic extract of $S$. collinitus showed p53-mediated effect on the normal cell cycle distribution and apoptosis induction in a human breast tumor cell line (Vaz et al., 2012). In another study, radical-scavenging and reducing power activities of $S$. collinitus were measured. In

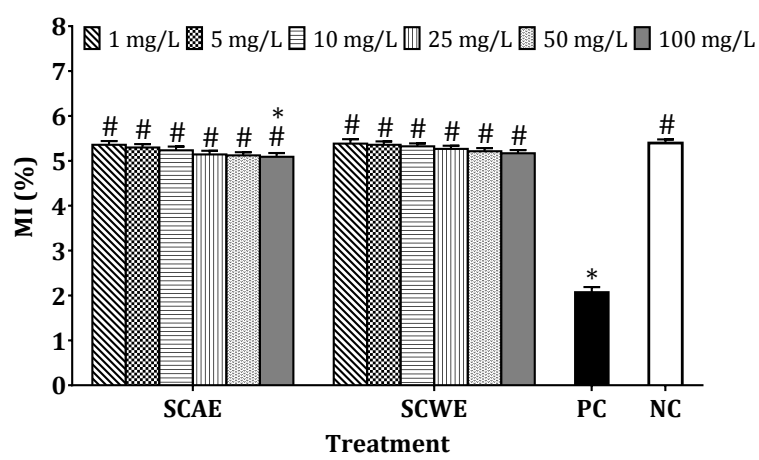

Figure 3. MI percentage in the lymphocytes exposed to $S$. collinitus extracts. Each value is expressed as mean \pm standard deviation $(n=3)$. * and \# symbols indicate statistical difference $(p<0.05)$ from NC and $\mathrm{PC}$, respectively.

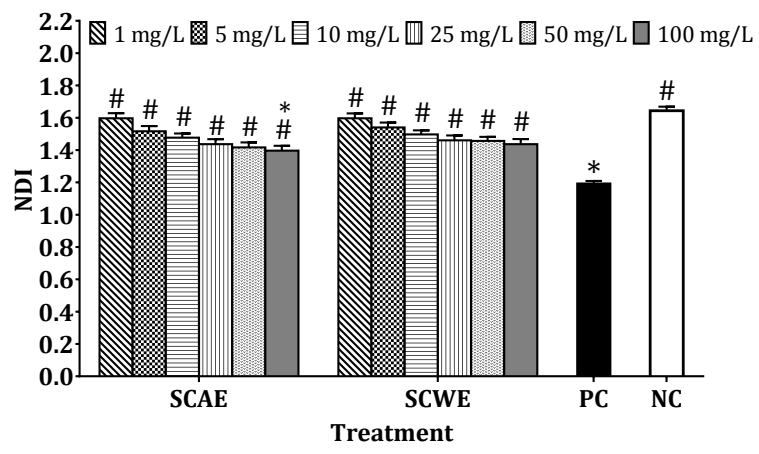

Figure 4. NDI in the lymphocytes exposed to $S$. collinitus extracts. Each value is expressed as mean \pm standard deviation $(n$ $=3$ ). $*$ and $\#$ symbols indicate statistical difference $(p<0.05)$ from NC and PC, respectively.

addition, inhibition of lipid peroxidation of $S$. collinitus in liposome solutions was determined and tocopherols composition of $S$. collinitus was found to be high (Heleno et al., 2010). Similarly, 1,1-diphenyl-2-picrylhydrazyl (DPPH) free radical scavenging rate of $S$. collinitus was found to be $71.94 \%$ by Akata et al. (2012). Froufe et al. (2011) revealed radical scavenging, reducing power and inhibition of lipid peroxidation activities of $S$. collinitus by calculating median effective concentration $\left(\mathrm{EC}_{50}\right)$ values $(14.05,2.97$ and $1.20 \mathrm{mg} / \mathrm{mL})$. The low $\mathrm{EC}_{50}$ values in the mentioned study revealed the high antioxidant capacity of S. collinitus.

Nowadays, there are increasing number of studies on medicinal mushrooms which are used as a support for the prevention and treatment of many diseases. It is seen that much more research is needed especially on the therapeutic effects of cultivated and wild edible mushrooms. In the light of the scientific results obtained in the present study, the antigenotoxic effect of $S$. collinitus on human lymphocytes will guide further studies.

\section{Acknowledgement}

The authors would like to thank Karamanoğlu Mehmetbey University Scientific Research Projects Commission for financial support (grant number 06-YL-19).

\section{Conflicts of interest}

There is no conflict of interest in any form between the authors. 


\section{References}

Akata I, Ergönül B, Kalyoncu F (2012). Chemical compositions and antioxidant activities of 16 wild edible mushroom species grown in Anatolia. International Journal of Pharmacology 8(2): 134-138.

Algar E, Dagar V, Sebaj M, Pachter N (2011). An 11p15 imprinting centre region 2 deletion in a family with Beckwith Wiedemann Syndrome provides insights into imprinting control at CDKN1C. Plos One 6(12): e29034.

Benítez G, Molero-Mesa J, González-Tejero MR (2017). Gathering an edible wild plant: food or medicine? A case study on wild edibles and functional foods in Granada, Spain. Acta Societatis Botanicorum Poloniae 86(3): 3550.

Breitenbach J, Kränzlin F (1995). Fungi of Switzerland, Vol. 4. Lucerne: Verlag Mykologia.

Chirapongsatonkul N, Mueangkan N, Wattitum S, U-taynapun K (2019). Comparative evaluation of the immune responses and disease resistance of Nile tilapia (Oreochromis niloticus) induced by yeast $\beta$-glucan and crude glucan derived from mycelium in the spent mushroom substrate of Schizophyllum commune. Aquaculture Reports 15: 100205.

De Silva DD, Rapior S, Fons F, Bahkali AH, Hyde KD (2012). Medicinal mushrooms in supportive cancer therapies: an approach to anti-cancer effects and putative mechanisms of action. Fungal Diversity 55(1): 1-35.

De Silva DD, Rapior S, Sudarman E, Stadler M, Xu J, Aisyah Alias S, Hyde KD (2013). Bioactive metabolites from macrofungi: ethnopharmacology, biological activities and chemistry. Fungal Diversity 62(1): 1-40.

Desjardin DE, Wood MG, Stevens FA (2014). California Mushrooms: The Compherensive Identification Guide. London: Timber Press,

Emsen B, Guven B (2019). Activities of two edible macrofungi, Coprinus comatus and Leucoagaricus leucothites in human lymphocytes: cytogenetic and biochemical study. Plant Biosystems epub ahead of print:1-8.

Emsen B, Guven B, Kaya A (2019). Antioxidant and antigenotoxic potential of Lycoperdon molle Pers., a wild edible mushroom. KSU Journal of Agricultural and Nature 22(5): 724-732.

Ergönül PG, Ergönül B, Kalyoncu F, Akata I (2012). Fatty acid compositions of five wild edible mushroom species collected from Turkey. International Journal of Pharmacology 8(5): 463-466.

Froufe HJC, Abreu RMV, Ferreira ICFR (2011). QCAR models to predict wild mushrooms radical scavenging activity, reducing power and lipid peroxidation inhibition. Chemometrics and Intelligent Laboratory Systems 109(2): 192196.

Gabory A, Attig L, Junien C (2009). Sexual dimorphism in environmental epigenetic programming. Molecular and Cellular Endocrinology 304(1-2): 8-18.

Gill BS, Navgeet, Mehra R, Kumar V, Kumar S (2018). Ganoderic acid, lanostanoid triterpene: a key player in apoptosis. Investigational New Drugs 36(1): 136-143.

Heleno SA, Barros L, Sousa MJ, Martins A, Ferreira ICFR (2010). Tocopherols composition of Portuguese wild mushrooms with antioxidant capacity. Food Chemistry 119(4): 1443-1450.

Hsieh T-C, Wu J. (2011). Suppression of proliferation and oxidative stress by extracts of Ganoderma lucidum in the ovarian cancer cell line OVCAR-3. International Journal of Molecular Medicine 28(6): 1065-1069.

Jordan M (1995). The Encyclopedia of Fungi of Britain and Europe. Devon: David \& Charles Book Co.

Kalač P (2013). A review of chemical composition and nutritional value of wild-growing and cultivated mushrooms. Journal of the Science of Food and Agriculture 93(2): 209-218.

Khatua S, Ghosh S, Acharya K (2017). Chemical composition and biological activities of methanol extract from Macrocybe lobayensis. Journal of Applied Pharmaceutical Science 7(10): 144-151.

Kumar S, Gupta SK, Sharma PK (2012). Recent developments in targeted drug delivery system for crossing bloodbrain barrier: a review. International Journal of Pharmacy and Pharmaceutical Sciences 4(2): 36-41.

Nguyet TMN, Lomunova M, Le BV, Lee JS, Park SK, Kang JS, Kim YH, Hwang I (2018). The mast cell stabilizing activity of Chaga mushroom critical for its therapeutic effect on food allergy is derived from inotodiol. International Immunopharmacology 54: 286-295.

Pala SA, Wani AH, Bhat MY (2013). Ethnomycological studies of some wild medicinal and edible mushrooms in the Kashmir Himalayas (India). International Journal of Medicinal Mushrooms 15(2): 211-220.

Rahman MA, Abdullah N, Aminudin N (2018). Evaluation of the antioxidative and hypo-cholesterolemic effects of lingzhi or reishi medicinal mushroom, Ganoderma lucidum (Agaricomycetes), in ameliorating cardiovascular disease. International Journal of Medicinal Mushrooms 20(10): 961-969.

Randhawa K, Shri R (2018). Comparison of antioxidant and anticholinesterase activities of selected Pleurotus species (Agaricomycetes) from India. International Journal of Medicinal Mushrooms 20(8): 739-748. 
Sangeetha K, Senthilkumar G, Panneerselvam A, Sathammaipriya N (2019). Cultivation of oyster mushroom (Pleurotus sp) using different substrates and evaluate their potentials of antibacterial and phytochemicals. International Journal of Research in Pharmaceutical Sciences 10(2): 997-1001.

Su S, Ding X, Fu L, Hou Y (2019). Structural characterization and immune regulation of a novel polysaccharide from Maerkang Lactarius deliciosus Gray. International Journal of Molecular Medicine 44(2): 713-724.

Valverde ME, Hernández-Pérez T, Paredes-López O (2015). Edible mushrooms: improving human health and promoting quality life. International Journal of Microbiology 2015: 1-14.

Vaz JA, Ferreira ICFR, Tavares C, Almeida GM, Martins A, Helena Vasconcelos M (2012). Suillus collinitus methanolic extract increases p53 expression and causes cell cycle arrest and apoptosis in a breast cancer cell line. Food Chemistry 135(2): 596-602.

Wang G, Zhang X, Maier SE, Zhang L, Maier RJ (2019). In vitro and in vivo inhibition of Helicobacter pylori by ethanolic extracts of lion's mane medicinal mushroom, Hericium erinaceus (Agaricomycetes). International Journal of Medicinal Mushrooms 21(1): 1-11.

Wang X-M, Zhang J, Wu L-H, Zhao Y-L, Li T, Li J-Q, Wang Y-Z, Liu H-G (2014). A mini-review of chemical composition and nutritional value of edible wild-grown mushroom from China. Food Chemistry 151: 279-285.

Zengin G, Sarikürkzü C, Aktümsek A, Uysal S, Ceylan R, Anwar F, Solak M (2015). A Comparative fatty acid compositional analysis of different wild species of mushrooms from Turkey. Emirates Journal of Food and Agriculture 27(7): 532-536.

Zhao X, Fang L, Liu D, Lai C, Zhang Y, Zhou A, Xie J (2018). A glucogalactomannan isolated from Agaricus bisporus induces apoptosis in macrophages through the JNK/Bim/caspase 3 pathway. Food \& Function 9(9): 4771-4780.

Cite this article: Emsen B, Türel A, Uzun Y (2019). Effects of Suillus collinitus (Fr.) Kuntze extracts on genotoxicity and proliferation of human lymphocytes. Anatolian Journal of Botany 3(2): 59-63. 